\title{
ETHNIC POLITICS, POLITICAL CORRUPTION AND POVERTY: PERSPECTIVES ON CONTENDING ISSUES AND NIGERIA'S DEMOCRATIZATION PROCESS
}

\author{
Dewale Adewale Yagboyaju \\ Obafemi Awolowo University, Nigeria
}

\section{Introduction}

It is common to interpret African politics in tribal or ethnic terms. In the case of Nigeria, the dominant political behaviour can be defined, on the one hand, in terms of "incessant pressures on the state and the consequent fragmentation or prebendalizing of state-power" (Joseph, 1991:5). On the other hand, such practices can also be related to "a certain articulation of the factors of class and ethnicity" (ibid). For a better understanding of the essentials of Nigerian politics and its dynamics, it is necessary to develop a clearer perspective on the relationship between the two social categories mentioned above and their effects on such issues as political corruption and poverty.

In order to do the necessary formulation that we pointed out in the foregoing, we need to know a bit about the history of Nigeria's birth. Designed by alien occupiers, through the amalgamation of diverse ethnic nationalities in 1914, Nigeria, as it is, cannot be 


\section{Ethnic Studies Review Volume 32.1}

called a nation-state. Although Nigerians are often encouraged to think of the country before their diverse ethnic origins, this seems to be an unattainable desire. Such a desire, if accomplished, will make Nigeria a unique African nation. However, behind the façade of ethnic politics in Nigeria, there are such other vested interests as class and personal considerations. Undoubtedly, all these combine to undermine the autonomy and functionality of the state in Nigeria. This, according to AbdulRazaq Olopoenia (1998:5), is so because "when the basis of social groups and their interest-group politics is ethnic fractionalization, a shared view of the imperative objectives of the power of the state will be difficult to establish".

Successive administrations in Nigeria have grappled with the challenge of overcoming the problems posed by this threat to democracy and development. Sadly, the net effect of the politics of ethnic fractionalization and its attendant consequences, especially political corruption, is the neglect of the mass of the Nigerian people. Hence, the country, which is ranked as a "developing nation" by the World Bank, United Nations (UN) and other international agencies, lacks the characteristics of a truly developing economy. I argued somewhere else that "despite the over $\$ 200$ billion that the country has generated from the exportation of crude oil since the late 1950s, more than half of its citizens live in abject poverty" (D.A. Yagboyaju, 2005:69). The people lack access to clean water, electricity, health facilities, transportation, communications and are largely unemployed because of the inefficient and ineffective management of sensitive public institutions. Majority of Nigerians are, therefore, disenchanted, while some others have confronted the various illegitimate and illegal regimes that existed in the country's entire civil-military political cycle. And in response, the various administrations dealt either lightly or heavily with such expressions. While some cajoled, others harassed, intimidated or, even, crushed by maiming or eliminating the brains behind such opposition.

In the light of the foregoing, this paper seeks to examine the exploitation of ethnic politics by the political and power elites in Nigeria. Notably, it will critically analyze the seizure of the state by the privileged few who; in a civilian administration, should be the representatives of the people, and under military rule, claim to 
intervene in order to correct certain anomalies caused by an inept civilian administration. In essence, it will discuss the endemic nature of political corruption and diversion of developmental funds, which have contributed to the soaring level of hunger, unemployment and poverty that characterize contemporary Nigeria.

Having done with the introductory aspect of the paper, the rest of the work is divided into four parts. These are namely, Definitional and Conceptual Issues; Characterization of the State and Politics in Nigeria; Matters Arising in the Fourth Republic; and Concluding Remarks.

\section{Definitional and Conceptual Issues}

The main concern of the paper in this section is the clarification of some relevant terms and concepts. These include ethnicity, political corruption and poverty. Such terms as "tribe", "inter tribal", "ethnic" and "ethnic nationalities" are, however, used interchangeably in the paper because of their closeness in meaning and interpretation. Perhaps the commonest explanation of what an ethnic group means is that which says that it comprises people with a common ancestry. In other words, this refers to people who can trace their pedigrees to one ancestor. Apparently, most definitions and explanations on the term, by social scientists, seem to draw from this perspective. Max Weber (1968:389), for instance, describes the ethnic group as "those human groups that entertain a subjective belief in their common descent".

However, more importantly and of greater relevance to this paper is its attribute which provokes deep emotions, "especially among people who belong to the same group within a bigger political community" (Yagboyaju, op cit). It is, for instance, not unusual to find members of a particular group evaluating other groups in terms of the standards of the former's own group. G.K. Nukunya (2003:21) describes this as "the subjective ascription of positive or negative attributes or characteristics to certain ethnic or tribal groups". In more specific terms, it means ascribing positive attributes to one's tribe or ethnic group and negative ones to others. When such attitudes are brought into the political arena, it is called ethnic politics.

Obviously, such attitudes pose debilitating threats to nation 


\section{Ethnic Studies Review Volume 32.1}

building and national integration. And, in the case of Nigeria, with about 250 ethnic nationalities, the politics of ethnicity has contributed more than any other factor to mutual fear of domination and general suspicion that have pervaded the landscape. We shall discuss more of this later in the paper.

It may be useful to begin our explanations on the concept of political corruption by borrowing from the folklore method of explaining corruption. It describes corruption as a kind of behaviour which deviates from the norm actually prevalent or desired in a given context. In this sense, many of the popular explanations of scholars on the subject are useful and informative. Per Bairamian (1995:30), for instance, defines "something corrupt" as "receiving or offering some benefit as a reward or inducement to sway or deflect the receiver from the honest and impartial discharge of his duties". For Andrei Shleifer and Robert Vishny (1993:599), the "sale of government property for personal gain by public officers" constitutes corruption. The foregoing explanations, no doubt are a bit narrow for obvious reasons. A more encapsulating definition is that given by Morris Szeftel (1998:221). He defines corruption as the "misuse of public office and public responsibility for private (personal or sectional) gain". Apparently, all these explanations and many similar others can be placed under Femi Odekunle's (1991:13) broad classificatory model which includes "economic/ commercial corruption", "administrative/professional corruption", "bureaucratic corruption" etc. Although most of these types of corruption have unique features, they often overlap.

In specific terms, political corruption can be defined as:

any act of a political elite, civilian or military, or any other highly placed public official, aimed at changing the normal or lawful course of events especially when the perpetrator uses such a position of authority for the purpose of a personal or group interest (such as acquiring wealth, status or power), at the expense of other interested parties (Yagboyaju, Op. Cit).

Our operational definition of political corruption is quite instructive. It crystallizes the abuse of public office and such other 
privileges by public officials for their own personal benefits or for those of some other narrow interest groups that they may represent. It takes different shapes and dimensions, which include intimidation, cajoling and, even, elimination of any form of opposition to the various illegitimate and illegal administrations that have been in place since political independence in Nigeria.

The two main concepts discussed in the foregoings are, undoubtedly, at the core of the intimidating challenge posed by poverty in contemporary Nigeria. But before we analyse this, we need to have a clear understanding of what constitutes poverty. According to the World Bank and United Nations (UN), in 1990 and 1995 respectively, poverty has various manifestations which include "lack of income and productive resources sufficient to ensure sustainable livelihood, or prevent hunger, malnutrition, ill health, limited or lack of access to education and other basic services". Others include the prevention of "increased morbidity and mortality from illness, homelessness, unsafe and degraded environment, social discrimination and exclusion" (ibid).

Several other view points have extended the explanations on poverty beyond the level of lack of sustainable livelihood, that is so common, to that of disempowerment. A popular explanation in this respect is the one offered by J. Friedmann (1996:161 - 172). He argues that the issue of poverty as it relates to disempowerment can be viewed from three angles, namely "social, political and psychological". He expatiates on the various dimensions thus:

Social disempowerment refers to poor people's relative lack of access to the resources essential for the self-production of their livelihood; political disempowerment refers to poor people's lack of a clear political agenda and voice; and psychological disempowerment refers to poor people's internalized sense of worthlessness and passive submission to authority.

Although the foregoing explanations on the subject of poverty may be clear enough, they are insufficient in measuring the level and other challenges of poverty. Undoubtedly, this latter aspect of the subject matter of poverty, is important for some reasons. One 


\section{Ethnic Studies Review Volume 32.1}

of such reasons is that it should enable developmental efforts to be channeled to the right groups and locations.

In line with the foregoing, J. Foster, et al (1984:761-765) explain that the most frequently used measures include:

(i) the head count poverty index given by the percentage of the population that lives in the household with a consumption per capital less than the poverty line; (ii) poverty gap index which reflects the depth of poverty by taking into account, how far the average poor person's income is from the poverty line; and (iii) the distributional sensitive measure of squares poverty gap defined as the mean of the squared proportionate poverty gap which reflects the severity of poverty.

Incidentally, this position on the methods of measurement buttresses some past efforts, while it is also supported by other more recent ones. In these respects, S. Aluko (1975), E.C. Edozien (1975) and M.L. Ferreira (1996) are quite relevant. Similarly, the United Nations Development Programme (UNDP) applies the Human Poverty Index ( $\mathrm{HPI}$ ) and Capability Poverty Measure (CPM) for the same purpose of measuring poverty level.

For instance, UNDP adopted the HPI in a 1997 report, which covered three dimensions of poverty in Nigeria.

These are namely:

Survival deprivation: measured as percent of people not expected to survive to age 40;

Deprivation in education and knowledge: percent of adults who are illiterate and;

Deprivation in economic provisioning: a weighted average of percentage population without access to safe water and health services, and percentage of underweight children under five years of age.

In more specific terms, the composite index showed that over the period 1990 - 96 "the intensity of deprivation and poverty in Nigeria was about the average for sub-Saharan Africa (SSA) and was further away from the best performing SSA country (Mauritius) than was to the worst performer (Niger Republic)". 
In effect, the foregoing, according to Olopoenia (1998:9), means that "the higher a country's HPI the more intensive is the degree of deprivation and hence poverty". In other words it means that Nigeria, in spite of its "phenomenal earnings from the exploration and exportation of crude oil, its great human resources and other extensive potentialities, is still predominantly poor" (Yagboyaju, op cit). Undoubtedly, this position of things depicts the character of a country that is yet to properly penetrate its society, and one which is also confronted by the challenge of democratic consolidation. We can have a better understanding by analyzing the character of Nigeria itself.

\section{Characterization of the State and Politics in Nigeria}

It may be appropriate to ask whether there is a nexus between the character of a state and such contending issues as ethnic politics, political corruption and poverty. Certainly there is a direct connection between the character of a state and the latter issues.

In the case of Nigeria, the character of the state cannot be discussed without referring to its colonial beginning. Historically, it was formed by the amalgamation of different ethnic nationalities, which may not have been possible without the superior fire-power and diplomacy of the British colonial authorities. In simple terms, the Nigerian state was an alien or artificial creation. This also means that the state, right from its birth, lacked some significant legitimating ideals.

In line with its forceful creation, it was not surprising that authoritarianism became a defining characteristic of the state. This, in addition to the fact that the colonial government hardly took any interest in social welfare, contributed to the raising of ethnic consciousness to more dangerous levels. Apparently, this was partly because some of the ethnic groups, unlike the colonial government, contributed in various ways; like education and social services, to the development of their indigenes.

Although ethnic consciousness may not be necessarily bad, various forms of abuse of the ethnic factor manifested with time. Some of the most disturbing have been analyzed by various scholars. These include K.W.J. Post (1973), Peter Ekeh (1975), 


\section{Ethnic Studies Review Volume 32.1}

Richard Joseph (1991), Claude Ake (1996) and Ukannah Ikpe (2000). A common line in the arguments and explanations of these scholars is anchored on the gradual emergence of such features as clientelism, prebendalism, patrimonialism and godfatherism in the operation of public affairs in Nigeria. The dangers associated with the features highlighted above include nepotism, administrative inefficiency, political corruption, poverty and political instability.

In a more concise form, Ake (op cit) summarizes the foregoings as the political questions $\mathrm{n}$ the character of the Nigerian state. This, he argues, has the following dimensions:

- A form of political competition in which people seek political power by all means, legal or not, with the result that politics is debased to warfare and the political system tends to break down.

- The prevalence of ethnic and sectional loyalties which prevent the emergence of national identity and collective purpose.

- A political leadership alienated from the masses and which maintains power without mandate and accountability.

- Political instability often manifest in disorderly and violent changes of the government in office.

Curiously, forty-eight years after its political independence in 1960, the Nigeria state is also negatively characterized by the social class factor. As this become more visible, it is also more deductible to argue that the Nigerian political elite and bourgeoisie may have fought the colonial system not only to change it, but, probably, also to inherit it for its own economic benefits. With its initial economic weakness, this group relied on politics and "used mass mobilization to come to power" (Ake, ibid).

Relatedly, the pervasiveness of state power in Nigeria, which makes its presence felt in almost all aspects of life, also makes its capture quite important. Amazingly, this is largely personalized and, expectedly, grossly abused by successive regimes in the country.

For a better understanding, we can apply two paradigms to explain this abuse. First, Frank Parkin's (1982) conceptualization of 


\section{Adewale Yagboyaju-Ethnic Politics, Political Corruption}

social closure is relevant. According to him, social closure is:

The process by which social collectivities seek to maximize rewards by restricting access to resources and opportunities to a limited circle of eligibles. This entails the singling out of certain physical attributes as the justificatory basis of exclusion. Virtually all group attributes - race, language, social origin, religion - may be seized upon provided it can be used for the monopolization of specific, usually economic opportunities... its purpose is always the closure of social and economic opportunities to outsiders.

Secondly, and probably, more appropriately, the World Bank illustrates this practice by its conceptualization of the term, state capture. According to the World Bank (2000:xv), state capture is:

The actions of individuals, groups, or firms both in the public and private sectors to influence the formation of laws, regulations, decrees and other government policies to their own advantage as a result of the illicit and nontransparent provision of private benefits to public officials.

The most important lessons to be drawn from the foregoings are two. First and foremost, ethnic consciousness and, by extension, ethnic politics, is mostly exploited by the Nigerian political and power elite, especially in contemporary times, for their own selfish and economic interests. Secondly, because the state is not able to maintain the position of an impartial public institution, it has, over the years, gradually lost its functionality and moderating role. This, in effect, means that it is unable to properly mediate the competition of political contestants and social classes; with the result that the privileged few continuously live in opulence, while the masses suffer abject poverty.

We are now well placed to understand the dynamics of sociopolitical and economic events, which have contributed to the endemicity of political corruption and soaring level of poverty, as we discuss matters arising in the present Fourth Republic.

\section{Matters Arising in the Fourth Republic}

Although so much has been documented on the negative effects 


\section{Ethnic Studies Review Volume 32.1}

of the annulled results of the 1993 presidential election in Nigeria, it is not surprising that it reverberates whenever the challenge of democratic consolidation, in the country, is being discussed. This, among other reasons, is that the annulment appeared to be the greatest threat, since after the civil war, to the continued existence of the country as a single entity.

Indeed, the June 12, 1993 election debacle, which started as a national issue, but which later had an ethnic colouration, was the most important among the major factors and forces that operated on the country's political scene in the mid and late 1990s. The struggle for the revalidation of the result of that election did not enjoy enough support from outside the winner, the late Chief M.K.O. Abiola's South-West ancestral home. Even with the "participation of some prominent Northerners, such as Adamu Ciroma, Balarabe Musa, Shehu Sanni, Dan Suleiman, Colonel Abubakar Umar (rtd), and a few others, in this struggle" the passivity of the generality of the Northerners created a negative impression" (Yagboyaju, Ibid). What this appeared to be, was that the average Northerner was unperturbed because Abiola's victory meant more political relevance for his Yoruba ethnic group. This was in spite of Abiola's transversing philanthropic gestures and expansive business links which, expectedly, should make him acceptable across the country. Therefore, it was not surprising that the Yorubas, Abiola's kinsmen, insisted that General Ibrahim Babangida, a Northerner, cancelled the election result just because the former was not from the Hausa/ Fulani dominated Northern zone of the country.

But, beyond this, there was another factor, which was, probably, known to the critical and analytical minds alone. And this was undeclared personal interest of the then military President, Babangida, to hang on to power for as long as he desired. Although unspoken, this interest was, probably, a major reason why the activities of the proponents of "Babangida must stay in office" were not checked by the then military ruler. However, the unrelenting efforts of pro-democracy activists and other professionals contributed, in no small measures, to the stepping-aside of the latter in November 1993. The Interim National Government (ING), a contraption left behind by the Babangida regime, was also forced 
to resign shortly after.

Amazingly, this multi-ethnic, divisive and conflictual nature of the country, which also evoked memories of the pre civil war days of 1967 was handled in a way that did not lead to another major crisis. However, rather than seize this great opportunity for the political development of the country, the succeeding General Sani Abacha military regime acted otherwise. The late Abacha, a Northerner, outlawed the then existing two political parties, called for the establishment of new ones and plotted a transmutation plan for himself. This plan ended with the death of Abacha in June 1998. While his death may have brought some relief to the country's political landscape, the mysterious death of Chief M.K.O. Abiola, shortly afterwards, renewed the apprehension in the country.

These operating forces and factors, therefore, provided the immediate background for some crucial decisions taken by the General Abdulsalami Abubakar military regime that took over after Abacha's death. Among other issues the regime contended with, three appeared more prominent. These were, namely the nagging problem of sharing and rotating political power among the ethnic groups, the sagging image of the military and the agelong struggle for genuine democratic rule in the country. It was noticeable, for instance, that even the military, whose privileged members benefited from its unduly long stay in power, knew that the entrenched nature of rule by successive military regimes proved exceedingly dysfunctional. For instance, Adekanye (2005:8) argues that the long stay "brought about not only a considerable distortion in the organisation's rank structure, hierarchy, system of discipline, and espirit de corps, but also a complete replacement of the ideals of asceticism, commitment to duty and patriotism, with money making and sheer careerism".

Apparently, in conformity with an aspect of most transitions from authoritarian rule, the then disengaging Abubakar military regime and the cartels of elite group interests engaged in some negotiated arrangements that led to the emergence of the then President Olusegun Obasanjo in 1999. Although the choice of Obasanjo, a Yoruba from the South-Western part of the country, should have ordinarily pacified this ethnic group; which was more affected by 


\section{Ethnic Studies Review Volume 32.1}

the controversial annulment of the 1993 election result, some other factors slightly affected it. First, Obasanjo did not identify with the struggle for the revalidation of that election result. Secondly, as a retired Army General, he was, most probably, chosen to protect the vested interests of the military. Incidentally, Obasanjo is the only Yoruba (Southwesterner), military officer among the various military rulers the country had between 1966 and 1999.

Based on the foregoing reasons and other similar ones, it may be appropriate to argue that the mere reintroduction of civil rule, the inauguration of the Obasanjo administration and its replacement, after eight years, by the Umaru Yar'Adua-led administration cannot automatically eradicate certain divisive tendencies that have, over the years, emanated from Nigeria's ethnic oriented politics. Rather, the challenge of managing the diversity of ethno-religious and cultural factors grows higher with the freedom of expression and association granted by liberal democracy and participatory governance. Certainly, this is a cross-cultural trend from which Nigeria cannot be excluded.

In the light of the foregoing, it is not surprising that pressures from the demands for recognition and attention from the different ethnic nationalities continued unabated. Even the South-West, the zone that largely benefited from the power rotation arrangement, at the inception of the Fourth Republic, also clamoured for the convocation of a national conference for the resolution of the national question. The comments made by Chief Emeka Anyaoku, former Secretary-General of the Commonwealth at that point in time were, therefore, instructive. According to him:

The pressures are already manifesting in a variety of forms. In the Niger Delta region of the country we have had agitations and violent campaigns resulting in significant loss of live and a measure of insecurity of the oil industry. In parts of the country especially the South-West zone, we have had calls and demonstrations for a sovereign National Conference with the aim of looking for a new basis for the co-existence of the country's different ethnic nationalities. And in the South-East zone, we see reports of complaints of alleged marginalization by the Federal Government (The 


\section{Adewale Yagboyaju-Ethnic Politics, Political Corruption}

Guardian, December 22, 2000, p.7).

Undoubtedly, these inter-tribal and ethnic pressures and the conflicts, which they generate occasionally, are disturbing and worrisome. But, the intra-ethnic and communal clashes that have been witnessed in many parts of the country, since the return of civil rule in 1999, are more alarming. Some available records show the dangerous dimensions of such communal clashes in the North-Central states of Benue, Taraba, Kaduna, Plateau, Nassarawa, Bauchi and Adamawa between 2000 and 2002. In fact, the violent nature of these conflicts between communities, who had hitherto co-existed peacefully, was the focal point of the then President Obasanjo's opening speech at a three day retreat on conflict resolution, in January 2002. In spite of this and several other similar efforts, intra-state and communal clashes were the major factors that were pronounced when, in 2003, emergency rule was declared in Plateau state.

If the continuously declining feeling of belonging, from the ordinary citizens, to the Nigerian state, is traceable to their ethnic attachments and other primordial sentiments, what then accounts for the intra-ethnic clashes? Can it be the economic interest of the power and political elite that we analyzed in a preceding section, or any other vested interest? According to Sam Egwu (2006:10), the underlying explanation for this "can be found in a number of factors that are embedded in the very nature of the Nigerian political economy". The one that is directly related to our own focus, out of these factors as listed by Egwu, links the use of state power by the political elites for primitive accumulation. What we are saying, in effect, is that political conflicts, violence and such others in Nigeria have shifting boundaries, and are only determined by the political elites who choose the appropriate strategy in the struggle for power.

In summary, the dimensions and forms that this politicization of ethnicity take include:

- North/South dichotomy which can be useful in the analysis of political violence at the national level.

- Inter-ethnic conflict which can be useful at both national and 


\section{Ethnic Studies Review Volume 32.1}

local (state) level, arising from the history of inter-group relations and the whole question of domination and exclusion in the exercise of power.

- Intra-ethnic conflict which can be useful in local conflicts. It can, however, be also as significant as inter-ethnic animosity. Among the Yoruba (Egba, ljesha, Owo, Ekiti, etc; among the Igbo (Orlu, Onitsha, Enugu East, Enugu West, etc), for example.

- Religious cleavages in some instances tend to reinforce ethnic and regional divisions because of overlap between ethnic and religious boundaries (Egwu, ibid).

In line with our thesis on the nexus between the politicization of ethnicity and perpetration of political corruption in the country; it may be useful to cite instances, during the present Fourth Republic, where politicians and other political elites from different ethnic backgrounds were involved in salacious deals. First, right from 1999 through the two terms of the then Obasanjo administration, and up till after the inauguration of the Third National Assembly in 2007, legislators at the national and local levels literally fought for huge allowances, salaries and other benefits that do not correspond with the present economic realities in the country. Yet, they belong to different ethnic groups and, sometime, political parties.

Secondly, the numerous financial scandals in the National Assembly, commencement of the Fourth Republic have cut across ethno-religious boundaries. These include the contract scandal that led to the removal of the late Dr. Chuba Okadigbo, Senators Gbenga Aluko, Khairat Gwadabe and a few others, as Senate President, Committee Chairman and members respectively in 2000; the bribe-for-budget approval scandal, which involved the then Education Minister, Professor Fabian Osuji, Chief Adolphus Wabara, then Senate President and other members of the Senate Committee on education in 2005; the National Identity Card Project scandal, which led to the removal of Chief S.M. Afolabi, one time Internal Affairs Minster, some PDP stalwarts and other officials in the State Assemblies, Executive Councils and other public institutions since the ministry; and several other cases like the ones that involved Mr. Tafa Balogun, one time InspectorGeneral of Police; the dismissal of Rear Admirals Francis Agbiti and 
Babatunde Kolawole, senior officers of the Nigeria Navy, in 2004; and many others.

But, of more relevance to our discussion were some cases that involved State Governors. For instance, D.S.P. Alamieyesiegha of Bayelsa state, one of the states in the troubled Niger Delta region, was removed for corruption in 2006. Although the process of his removal was criticized for being selective and patchy, it was still manifestly clear that the huge special allocations for Bayelsa, just like such other states in the region as Edo, Rivers and Delta were not judiciously applied. The widely reported investigations of Chiefs Lucky Igbinedion, Peter Odili and James Ibori, immediate past Governors of the latter states respectively, also justify our position here. These instances highlighted above are, no doubt, just few of the numerous ones across the country, but they are of a peculiar nature. This peculiarity draws from the fact that they are all states from the oil-rich Niger Delta region where a prudent and equitable application of resources may have, probably, reduced the tension and threat to national security that have characterized the activities of ethnic minority and militia groups, over the years.

On a higher scale, however, the numerous allegations of corruption against Chief Obasanjo, the immediate past President; if they are eventually established, may have graver consequences for the country's democratization process, its national unity and the ruling PDP's special zoning arrangement which produced the incumbent Vice President, Goodluck Jonathan, from the ethnic minorities of the Niger Delta region. This is particularly so because, by implication, it can be applied to justify all the allegations of bribery that were levelled against the former President on the botched attempt to illegally elongate his tenure, in the twilight of his stay in power.

Relatedly, the fluidity of the party system and "the associated complexity in the political pacts and alliances of the ruling elite" (Egwu, op cit), also define the nature of the politicization of ethnicity and the accompanying abuse of privileges in the country. This, for instance, is characterized by two contradictory tendencies. First, is the multi-polar tendency that is reflected in the emergence of a multiparty system during periods of electoral politics; as was 


\section{Ethnic Studies Review Volume 32.1}

the case in the First, Second and the present Fourth Republics. Secondly, there is the usual tendency for political re-alignments after a party has been declared winner. It is usually the fusion of prominent members of the losers parties with the victorious party, or the formation of two broad coalitions of competing political elite. Apparently, one recurring negative feature of the party system is its winner-takes-all character. And this, in conformity with Paul Collier's (2007) analysis of "performance politics and identity politics", worsens deprivation and poverty.

For a better understanding, Collier's analysis on these types of politics emphasises that:

Performance politics is associated with genuine democracy in which free and fair elections are the norm. The system ensures, among other things, that all those qualified to vote can obtain voters cards; and voters are guided by issues and principles, not personalities.

In contrast to this, in identity politics, citizens are reminded of their differences. Their loyalty to a party is maintained, irrespective of the performance and reputation of the party. Governments, on the other hand, deliver patronage to loyalists rather than services to the generality of the people.

Although there are elements of identity politics in some developed democracies too, they are not significant to the extent of making profound impacts on the systems. For instance, in the United States of America (USA) where issues of ethnic minorities also generate concern, the victory of Barack Obama, as the presidential candidate of the Democrats, is enough to show that performance eventually over-shadowed sentiments. And, for Obama himself, change and better service delivery to all, have been the watch words. Certainly, all of these make the difference in the developed world. Nonetheless, the final outcome of the US presidential elections in November 2008 poses a great challenge to that country's political life.

In Nigeria, poverty level is worsening as unemployment is soaring. This negates reports by such international agencies as the 
Paris Club and World Bank, which asserted economic growth, in the country, in recent times. Even if the claim of macro economic growth is justifiable, there is no correspondent human capital development. While the quality of education, health and other social services is dwindling all over the country, the agriculture, general merchandising and other similar sectors which, hitherto, provided employment for the ordinary citizens have become very unattractive. In a similar vein, the crushing effects of the various economic reforms initiated by the immediate past Obasanjo administration, and partly continued by its successor, have also contributed to the hardship experienced by the masses. Amazingly, government has also not deemed it fit to review the salaries of ordinary workers in the public sector. Similarly, it is yet to fully resolve the perennial problem of pension arrears in the country.

Finally, a particularly worrisome aspect of the issue of poverty in Nigeria has to do with the country's apparent ill-preparedness for the impending global food and financial crises. The net effect of this is that more and more Nigerians will, most probably, be pilloried into docility, wherein they will further lose interest in participating in public affairs. In effect, democratic rule and its consolidation are further exposed to threats as exploiters and predatory rulers shall continue to predominate the political landscape.

\section{Concluding Remarks}

The extensive literature on the politicization of ethnicity in Nigeria, part of which we consulted in the foregoing discussion, confirms the abuse of public office and the accompanying privileges, through such practices as clientelism, patrimonialism, prebendalism, godfatherism and cronyism, by the political elite and other highranking public officials. Although ethnic consciousness may necessarily not be negative, its application for some narrow vested interests has, over the years, worsened various socio-political and economic problems. Among these, political corruption and poverty stand out. Incidentally, they are both serious threats to national integration and the democratization process in the country.

In our own opinion, this situation may deteriorate except urgent and concerted efforts are made in the following directions: 


\section{Ethnic Studies Review Volume 32.1}

- Convocation of a plebiscite or a referendum on the preparation of a people-oriented constitution to replace the present one.

- Restructuring of the present components of the federation in such a way that local governments and other sub-units, that are closer to the ordinary people, are granted more powers.

- Restoring the autonomy and functionality of public institutions by separating them from the personalities of office holders.

- Encouragement of more and more enlightened Nigerians in participating in public affairs, right from the grassroots.

- Renewed encouragement of such institutions as the National Football Team, National Youth Service Corps (NYSC), Nigeria Army, etc.

\section{References}

Adekanye, Bayo (2005). "Reforming the Character of Civil-Military Relations for Democratic Governance in Nigeria After 1999", Distinguished Lecture Series, No.8, Faculty of Social Sciences, University of Lagos.

Ake, Claude (1996). "The Political Question", in Oyeleye Oyediran (ed.) Governance and Development in Nigeria: Essays in Honour of Professor Billy J. Dudley, Ibadan: Oyediran Consults International.

Aluko, S. (1975). "Poverty: Its Remedies", in Poverty in Nigeria. The Nigeria Economic Society.

Anyaoku, Emeka (2000). "How to manage Nigeria's diversity", The Guardian Newspaper (Nigeria), $22^{\text {nd }}$ December, p.7.

Bairamian, Per (1995) Obaku Vs. Nigeria Police, N.L.R. 20.

Collier, Paul (2007). "Performance Politics and Identity Politics"; the report of this study was cited in the Punch newspaper, Thursday, April 26, p. 16.

Edozie, E.C. (1975). "Poverty: Some Issues in Concept and Theory", 


\section{Adewale Yagboyaju-Ethnic Politics, Political Corruption}

in Poverty in Nigeria, Op. Cit.

Egwu, Sam (2006). "The Context and Lessons of the 2003 Elections in Nigeria", in I.O. Albert et al (eds.) Conflict Tracking Dossier, a Quarterly Journal of the Institute for Democratic Alternative in South Africa (IDASA), Abuja: IDASA.

Ekeh, Peter (1975). "Colonialism and the two Publics in Africa: A Theoretical Statement", Comparative Studies in Society and History, 17(1): 91-112.

Ferreira, M.L. (1996). "Poverty and Inequality during Structural Adjustment in Rural Tanzania", World Bank Policy Research Working Paper, No. 1641.

Foster, J. et al. (1984). "A Case of Decomposable Poverty Measures", Econometrica, Vol. 52, pp. 761-765.

Friedmann, J. (1996). "Thinking Poverty: Empowerment and Citizens Rights", International Social Sciences Journal, No. 148, pp. 161-172.

Ikpe, Ukanna (2000). Political Behaviour and Electoral Politics in Nigeria, Uyo: Golden Educational Publishers._

Joseph, Richard (1991). Democracy and Prebendal Politics in Nigeria: The Rise and fall of the Second Republic, Ibadan: Spectrum Books Ltd.

Nukunya, G.K. (2003). Tradition and Change in Ghana: An Introduction to Sociology, Legon: Ghana University Press.

Odekunle, Femi (1991). "Controlling Indiscipline and Corruption in Nigeria: Fundamental and Short Term Measures", in Perspective on Corruption and other Economic Crimes in Nigeria, Federal Ministry of Justice, Lagos.

Olopoenia, Abdul Razaq (1998). "A Political Economy of Corruption 


\section{Ethnic Studies Review Volume 32.1}

and Underdevelopment", Faculty of the Social Sciences Lecture Series, No. 10, University of Ibadan.

Parkin, Frank (1982). "Social Closure and Class Formation", in Anthony Giddens \& David Held (eds.), Classes, Power and Conflict: Classical and Contemporary Debates, Berkeley: University of California Press.

Post, K.W.J. \& Michael Vickers (1973). Structure and Conflict in Nigeria (1960 - 1966),London: Heinemann.

Shleifer, Andrei \& Robert Vishny (1993). "Corruption", The Quarterly Journal of Economics, 108(3), p. 599.

Szeftel, Morris (1998). "Misunderstanding African Politics: Corruption and the Governance Agenda", Review of African Political Economy (ROAPE), No. 76, p. 221.

United Nations (1995). "The Report of the World Summit for Social Development", Copenhagen Declaration and Programme of Action, March $16^{\text {th }}-22^{\text {nd }}$

United Nations Development Programme (UNDP) (1997). Nigeria: Human Development Report, Lagos.

(UNDP) (1998). Nigeria: Human Development Report, Lagos.

Weber, Max (1968). Economy and Society, New York: Bedminster Press.

World Bank (1990). Poverty (World Development Report), New York: Oxford University Press.

World Bank (2000). Anti-corruption in Transition: A Contribution to the Policy Debate, The World Bank, Washington: The World Bank.

Yagboyaju, D.A. (2005). “Ethnicity, Political Corruption and Poverty: A 
Adewale Yagboyaju-Ethnic Politics, Political Corruption

Trigonometric Force Against Peaceful Coexistence and Participatory Democracy in Nigeria's Fourth Republic", African Conflict Profile, Journal of the Centre for Ethnic and Conflict Studies (CENTECS), University of Port Harcourt, Vol. 1, No.2, p. 69. 